\section{Uranium bites dust}

The British government seems bent on letting past investments in nuclear power be wasted.

THE British seem to have a flair for indecision from which even the present decision-prone government is not immune. The failure to decide what should happen to the goods and people delivered to South-East England by the Channel Tunnel a few years from now would be a joke were it not likely to become a reality. Now, a modest programme of nuclear construction has been abandoned after a decade's costly effort by engineers, bureaucrats and lawyers, but for reasons not strictly concerned with the safety of nuclear power or with long-term economics. It is as if the British government shares with its predecessors a liking for the sensation of sand running through its fingers.

Ten years ago, the government came to office with a plan for building nuclear reactors to the Westinghouse pressurized-water design at the rate of roughly one a year. Construction of the first generating station (with two reactors) began two years ago at Sizewell in Suffolk, on the North Sea coast. The project has been enormously delayed by the decision that a public planning inquiry should be a 'generic' inquiry, dealing with general matters as well as the suitability of the site. The hope was to save time later in the construction programme. But the second public inquiry, in respect of a site at Hinckley Point on the Somerset coast (which closed last week) has been almost as long and painstaking. Indeed, the inquiry outlasted the nuclear programme itself, which was formally put on ice last month.

The explanation is simple, but not straightforward. The British nuclear programme has been a casualty of the government's determination to sell the electricity industry to private investors. The first stages of this huge exercise will begin next year, with the privatization of the electricity distribution companies. The sale of the generating plants, which will follow in 1991, has always seemed more complicated. Originally, it was planned that there should be two generating companies (one large and one small called National Power and Powergen respectively) to simulate competition. Now there is to be a third, whose plant will consist of all the nuclear stations operating or being built. It may just be on the point of going out of business when the greenhouse effect prompts another British nuclear programme.

The origins of this development are not obscure, but concern the high costs of operating a series of unsuccessful and uneconomic reactors called AGRs (for "Advanced Gas Cooled") as well as the estimated costs of decommissioning a previous generation of reactors. National Power, the larger of the generating companies which was to have had responsibility for nuclear generation, may now kick itself for have lobbied so successfully to shield its future shareholders from hardship by 600 frightening the government with worst-case costs.

The effects of the decision are nevertheless curious. The new nuclear company will be cast in the mould of the Atomic Energy Authority created in the 1950s as the spear-carrier of the new nuclear industry. Over 40 years, the authority has consumed a substantial fraction of Britain's engineering skill, together with substantial amounts of money. It remains a technically excellent organization, but without a nuclear programme, it might as well be renamed (its Harwell laboratory has become an excellent engineering and materials laboratory) or even be wound up when the fast reactor programme in Scotland comes to an end. Future British governments may find it simpler, on future occasions, just to dig holes in the ground and fill them in again.

\section{Generating physicists}

A British minister hopes that compulsory physics will make more physicists, but he could be wrong.

STUNG by the example of the Japanese, all industrialized states are these days worrying about the sufficiency of the supply of technical people, scientists and engineers in particular. Generally speaking, there are too few of them. Generally speaking, the poorer industrialized economies are the most deprived. There is no accident in that: science education costs time and money, at least in comparison with the language and literature of the region (unless, ironically, the language is Japanese). Even so, it is curious that one of the British government's least celebrated innovations of the past few years is the introduction of a national curriculum for primary and secondary schools, partly with the objective of increasing the supply of scientists and engineers. How will it work out?

To judge from what Mr Alan Howarth, a minister at the British Department of Education and Science, was saying the other day, not much has changed. Speaking to the Institute of Physics, Howarth said last month that the national curriculum, by introducing students to physics at an early age, must eventually increase the supply. But the truth could easily be quite different. Past experience in British schools with the old curriculum, allowing for specialization at too early an age, shows that there is nothing like a poor teacher to drive young people into other pursuits. Howarth was promising more teachers the other day, but will they be good teachers? And if not, may it not be the worse for science education that young people should be forced to sit through classes that will convince them that they should opt for the arts and humanities?

If Howarth really had the supply of technical people at heart, he would settle instead for a compulsory curriculum that did hardly more than persuade young people that these technical fields are interesting and important, letting them learn to be professionals when they are ready for the task. 